\title{
Chemical Study and Determination of the Antioxidant Activity of Three Varieties Tropaeolum tuberosum (Mashua)
}

\author{
Jiménez Heinert María Elena1 ${ }^{(0)}$, Gutiérrez Gaitén Yamilet Irene ${ }^{2}{ }^{(0)}$, \\ Yamilet Guaranda Iván ${ }^{3}$ (i), Miranda Martínez Migdalia ${ }^{*}$ (i)
}

${ }^{1}$ Jiménez HeinertMaría Elena, Chemical Sciences Faculty, Guayaquil University, Guayaquil, Ecuador

${ }^{2}$ Gutiérrez GaiténYamilet, Pharmacy and Food Institute, Havana University, Havana, Cuba

${ }^{3}$ ChóezGuarandaIván, Biotechnological Research Center of Ecuador, Polytechnic School of the Coast, ESPOL, Guayaquil,

Ecuador

${ }^{4}$ Miranda Martínez Migdalia, Chemical and Environmental Sciences Department, Natural Sciences and Mathematics Faculty, Higher Polytechnic School of the Coast, ESPOL, Guayaquil, Ecuador

Email: maria.jimenezhe@ug.edu.ec, yamiletgg@ifal.uh.cu, iachoez@espol.edu.ec,*mgmiran@espol.edu.ec

How to cite this paper: Elena, J.H.M., Irene, G.G.Y., Iván, Y.G. and Migdalia, M.M. (2019) Chemical Study and Determination of the Antioxidant Activity of Three Varieties Tropaeolum tuberosum (Mashua). American Journal of Plant Sciences, 10, 2279-2297. https://doi.org/10.4236/ajps.2019.1012159

Received: November 9, 2019

Accepted: December 24, 2019

Published: December 27, 2019

Copyright (c) 2019 by author(s) and Scientific Research Publishing Inc. This work is licensed under the Creative Commons Attribution International License (CC BY 4.0).

http://creativecommons.org/licenses/by/4.0/

\begin{abstract}
Ecuador has among its foods a number of potatoes and tubers that are not only nutritious, but are also attributed properties as coadjutant in the treatment of different illnesses. The objective of this study was to conduct a comparative study of the mashua tuber (Tropaeolum tuberosum spp tuberosum Ruíz \& Pavón, Kuntze), in its three pink, yellow and black varieties, by comparing the physicochemical characteristics and antioxidant activity. The comparative study was carried out on tubers obtained in the province of Pichincha, Quito-Ecuador. The physicochemical parameters were determined by the identification of the secondary metabolites present in the hydroalcoholic extracts, the quantification of phenols and flavonoids, and the characterization of the extracts by gas chromatography coupled to mass spectrometry and the antioxidant activity by three test methods. As a result, significant differences were found between the three varieties studied.
\end{abstract}

\section{Keywords}

Antioxidant Activity, Chemical Composition, Gas Chromatography-Mass Spectrometry

\section{Introduction}

Food and health at a global level are a growing concern between different gov- 
ernments looking for a solution without altering local customs in every country. This has led to a search into traditional, natural resources, which may have not been properly distributed, being ignored among Ecuadorian populations [1].

Looking back at these traditional products, they noticed an Andean tuber and investigated its nutritional and pharmacological qualities of ancestral use [2].

Tropaeolum tuberosum Ruíz \& Pavón, Kuntze (mashua), a Tropaeolaceae family tuber which grows between 2400 and 4300 m.a.s.l, was discovered in the Andes, covering the countries of Venezuela, Colombia, Ecuador, Perú, Bolivia, Chile and Argentina. It is ranked in fourth of nutritional tubers after potatoes, oca and olluco [3] [4]. On the other side, several studies have shed light upon its medicinal properties to relieve kidney and liver diseases [5], skin eczema, prostate disease and diabetes. These therapeutic properties would be related to the presence of phenolic antioxidants and these due to the high anthocyanins contents [6] [7].

Diversity among mashua tubers comes in differences in shape, color, pulp color, knob characteristics. Skin color varies from white to violet or dark purple, yellow, orange, red, pink, being possible to have one color only or different spots. In general, they have a high protein content, carbohydrates, fiber, ascorbic acid and calories [8].

A study from Campos et al. [9], to compare the antioxidant potential of some Andean crops, including colored potatoes, olluco and oca, showed that purple mashua tubers showed the highest antioxidant activity, eight or ten times higher than that of yellow mashua tubers. This superior activity was thought to be related to the high anthocyanin content. Afterwards, Chirinos et al. [6] [10] [11] [12], found that not only the mashua anthocyanin where contributing but also the phenols played an important role in the antioxidant power of the tubers. The main anthocyanins found in the different genotypes of mashua are delphinidin di- and acylated triglycosides with acetic acid. Cyanidins and pelargonidins are also present in minor quantities.

Despite these results, the different varieties lack pharmacognostic and phytochemical studies to support the ethnopharmacological uses against urinary, genital diseases, antibiotic, and depressor of the erectile function in men.

The yellow is the variety most commonly used, of better flavor and easiest to obtain, while the pink and black are available only from March to May, or directly from the owners of the crop.

The objective of this work was to determine and compare the physicochemical and antioxidant activity from the tuber Tropaeolum tuberosum spp tuberosum (Ruíz \& Pavón, Kuntze) in its three varieties to learn more about their similarities and differences.

\section{Materials and Methods}

\subsection{Collection, Drying and Grinding}

The collection of different varieties took place at the Pichincha province, 
Quito-Ecuador at 3360 m.a.s.l., with the following coordinates: $0^{\circ} 13^{\prime} 47.5^{\prime \prime S}$ $78^{\circ} 31^{\prime} 29.8^{\prime \prime}$, on April the 2018. The selection was done according to the size, color and weight, and was washed with a solution of sodium hypochlorite at 1\%, then washed with potable water, drained, sliced and dried on a Teknolab SA stove at $50^{\circ} \mathrm{C} \pm 3^{\circ} \mathrm{C}$ until the weight was constant. Afterwards, it was grinded in a PULVEX brand knife mill with $2 \mathrm{~mm}$ mesh.

\subsection{Physical Chemical Parameters and Phytochemical Screening}

For the powder of the three varieties, the physical chemical parameters were determined by triple (residual humidity, total ashes, ashes soluble in water and ashes not soluble in chlorhydric acid), by following the procedures described by WHO [13].

The phytochemical screening was done with dried tubers, according to the procedures described by Miranda and Cuellar [14]. An extraction system with a battery of solvents, from minor to major polarity, on the same vegetable material, to achieve that each metabolite was extracted correctly according to the selectivity of each solvent. The samples were extracted with ethyl ether, ethanol and water, to obtain the extracts which were used in the experiments.

\subsection{Obtaining the Extracts}

From the vegetable material we elaborated hydro alcoholic extracts at $30 \%$ of $20 \mathrm{~g}$ of drug for each $100 \mathrm{~mL}$ of solvent, by maceration for seven days. We followed the procedure described by Miranda y Cuéllar [14].

\subsection{Physical Chemical Parameters of the Quality of the Extracts}

The quality of the extracts was determined by the procedure described by Miranda and Cuéllar [14]. Each experiment was repeated three times, evaluating the following parameters: organoleptic properties, total solids, refractive index, and relative density.

\subsection{Quantification of Total Phenols}

The total phenol content was determined by the method Folin-Ciocalteu [15] [16] [17] [18]. A dilution of 1:2 (extract: water, v:v) was done. As reference substance we used gallic acid at concentration levels of 10,20,30, 40 and 50 $\mathrm{mg} / 100 \mathrm{~mL}$ and we constructed an absorbance calibration curve against concentration of the patterned mentioned, and from this we determined the concentration of phenols in the extract on $\mathrm{mg} / \mathrm{mL}$ [Figure 1], where a good correlation between the tested concentrations of the reference substance (gallic acid) and absorbances is shown, with a correlation coefficient $\geq 0.99$.

\subsection{Quantification of Total Flavonoids}

The method used was the colorimetric method of aluminum trichloride [15] [19].

A dilution of 1:5 (extract: water, v:v) was performed. As reference substance 
we prepared a mother solution of quercetin $10 \mathrm{mg} / \mathrm{mL}$ in ethanol at $96 \%$, and from there we prepared solutions of concentrations of 5, 20,50, 60 and 80 $\mu \mathrm{g} / \mathrm{mL}$. We constructed an absorbance calibration curve for the pattern and determined the flavonoid concentration for the extract expressed in $\mathrm{mg} / \mathrm{mL}$. A good correlation was achieved between the tested concentrations of the quercetin pattern and the absorbances, obtaining a correlation coefficient $\geq 0.99$; this is a good indicative of the experimental data model [Figure 2].

\subsection{Analysis of the Extracts by the Coupled Gas Chromatography-Mass Spectrometry System}

Dried samples were mixed with N-Trimethylsilyl-N-methyl trifluoroacetamide (MSTFA), and heated in a water bath to $80^{\circ} \mathrm{C}$ for 2 hours to permit the silylation of metabolites [20]. Next, GC-MS analysis was performed in a gas chromatography mass spectrometry equipment Agilent Technologies (7890A GC system and 5975C inert XL MSD with triple axis detector). A capillary column DB-5MS (30 $\mathrm{m} \times 0.25 \mathrm{~mm}$ ) with phenyl dimethylpolysiloxane was used as stationary phase (0.25-micron film thickness) and helium as the carrier gas (1.2 $\mathrm{mL} / \mathrm{min}$ ). The injection of $1 \mu \mathrm{L}$ of derivatized sample was performed at $250^{\circ} \mathrm{C}$ with splitless mode. The oven temperature was started at $70^{\circ} \mathrm{C}$ for 2 minutes, then it was increased to $300^{\circ} \mathrm{C}$ at $5^{\circ} \mathrm{C} / \mathrm{min}$, and it was maintained at $300^{\circ} \mathrm{C}$ for 6 minutes. The compounds identification was done by comparison of mass spectra based on Wiley $9^{\text {th }}$, and NIST 2011 MS Library. An electron ionization of $70 \mathrm{eV}$ at

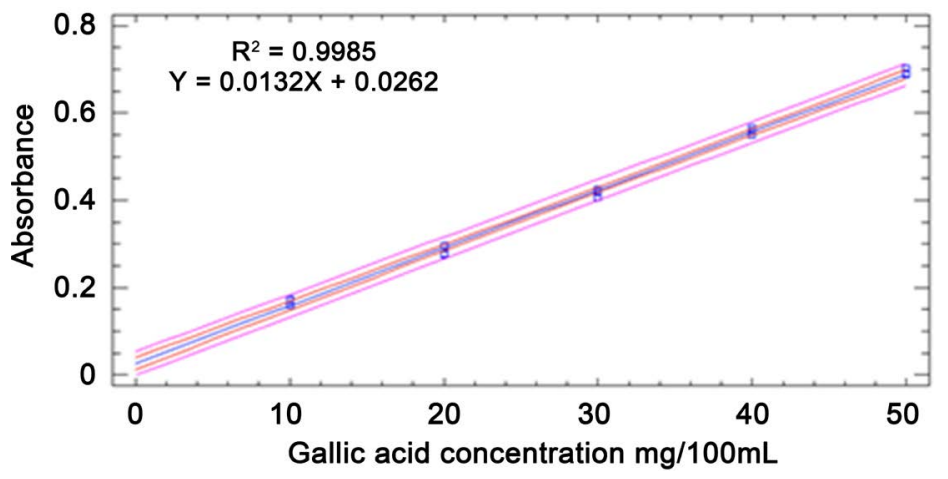

Figure 1. Calibration curve of gallic acid for the determination of total phenols.

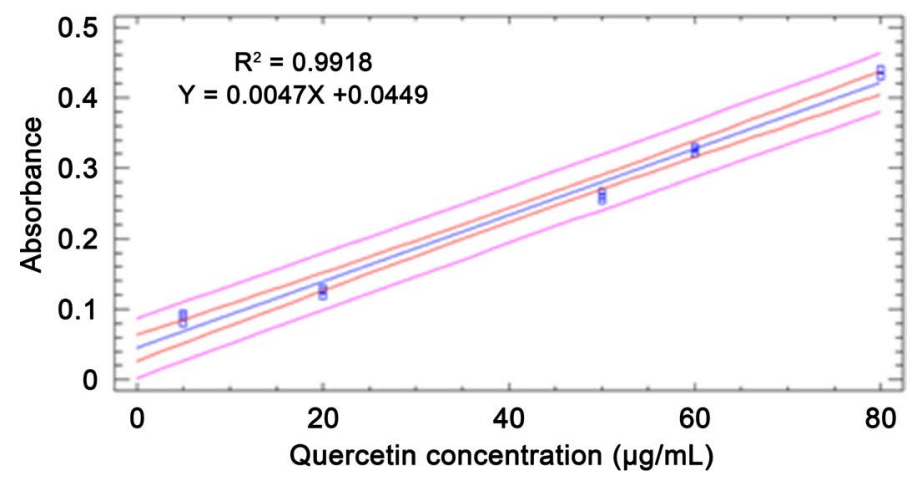

Figure 2. Quercetin calibration curve for the determination of total flavonoids. 
$230^{\circ} \mathrm{C}$ was used in the ion source and the data compounds were collect with the full scan mode (40 - $600 \mathrm{amu}$ ) in the quadrupole mass analyzer.

\subsection{Determination of Antioxidant Activity}

The determination of the antioxidant activity was carried out by three methods: ferro-reducing activity, sequestration capacity of the DPPH radical and percentage inhibition of the ABTS radical.

Antioxidant activity by the FRAP method (ferro-reducing capacity): The capacity to reduce hydroalcoholic extracts was measured according to the procedure described by Benzie y Strain [21]. The determinations were spectrophotometric, a UV spectrophotometer was used (Rayleigh UV-1601, Shanghai, China) at an absorbance of $593 \mathrm{~nm}$. The results were expressed as $\mu$ mol equivalents of ascorbic acid (EAA) and as $\mu \mathrm{mol}$ equivalents of $\mathrm{FeSO}_{4}$, from the calculation interpolating the optical density (OD) of the samples in the calibration curves of both reference substances at concentrations of 50,100, 200, 400 and $500 \mu \mathrm{M}$. The readings were made in triplicate at four minutes.

Sequestration capacity of the 2,2-diphenyl-1-pyrylhydrazyl radical (DPPH): For the quantitative determination the DPPH free radical method was used [22] [23]. A UV-visible spectrophotometer was used and the determinations were measured at $517 \mathrm{~nm}$ after $30 \mathrm{~min}$. The results were expressed as percentage inhibition of the DPPH radical.

ABTS test $\bullet+(2,2$ '-azino-bis(3-ethylbenzothiazoline) -6 -sulfonic acid): The test was performed according to the methodology of Re et al., Agudo y Arnao et al. [24] [25] [26]. The results were expressed as percentage inhibition of the radical ABTS $\bullet$. The mean inhibitory concentration (IC50) was determined with the help of the statistical program Graphprism 5.0.

\subsection{Estatistical Analisys}

The results of the quality control of the drugs and extracts and the determination of the total phenols and total flavonoids, were processed to calculate the medium values and the standard deviations. The program Statgraphics ${ }^{\circledR}$ Plus, version 5.0 was used with a normality test (Kolmogorov-Smirnov), after which an analysis of variants and for the comparison of the Duncan's stockings.

The statistical program SPSS for Windows version 8.0 was used for the processing and statistical analysis of the results of the antioxidant study. The experimental values were expressed as the mean \pm standard deviation (SD). The data was analyzed by one-way ANOVA, followed by a test of multiple comparisons of Tukey means with a $p \leq 0.05$.

\section{Results}

\subsection{Physical Chemical Parapemeters of the Vegetable Material}

For the results of the physical chemical parameters the results are shown in [Table 1].

All parameter where within the ranges informed by Pharmacopeas. 


\subsection{Phytochemical Screening of Plant Material}

A qualitative analisys to a different variety of mashua was done, in order to determine the secondary metabolites present in each of them and the results are presented in [Table 2].

\subsection{Organoleptic Parameters, Physical Chemical, and Phytochemical Screening of the Extracts}

With the purpose of determining the quality of the extracts, we did a physical chemical parameter analysis, considering the organoleptic properties (odor and color), $\mathrm{pH}$, total solids, refraction index and relative density; in Table 3 we present the results of the study.

Table 1. Physical-chemical parameters of the powdered drugs of the three varieties of Mashua.

\begin{tabular}{cccc}
\hline \multirow{2}{*}{ Parameters } & \multicolumn{3}{c}{ Variety } \\
\cline { 2 - 4 } & Yellow & Pink & Black \\
\hline Total humidity (\%) & $92.86 / 0.04$ & $90.26 / 0.07$ & $91.77 / 0.56$ \\
Residual humidity (\%) & $7.09 / 0.08$ & $6.59 / 0.10$ & $8.23 / 0.05$ \\
Total ashes (\%) & $3.9 / 0.11$ & $3.48 / 0.20$ & $5.09 / 0.10$ \\
HCl insoluble ashes & $0.37 / 0.10$ & $0.31 / 0.003$ & $0.15 / 0.02$ \\
\hline
\end{tabular}

Legend: X/S average value/standard deviation, $\mathrm{n}=3$.

Table 2. Phytochemical screening of the tubers of the three varieties of T. tuberusum.

\begin{tabular}{|c|c|c|c|}
\hline \multirow{2}{*}{ Metabolite } & \multicolumn{3}{|c|}{ Variety } \\
\hline & Yellow & Pink & Black \\
\hline \multicolumn{4}{|l|}{ Ethereal extract } \\
\hline Oils & ++ & + & ++ \\
\hline Alkaloids & +++ & - & +++ \\
\hline Lactones & ++ & - & - \\
\hline Triterpenes/Steroids & +++ & - & ++ \\
\hline \multicolumn{4}{|l|}{ Alcoholic extract } \\
\hline Reducing compounds & +++ & + & +++ \\
\hline Alkaloids & +++ & - & - \\
\hline Lactones & +++ & - & - \\
\hline Triterpenes/Steroids & +++ & - & ++ \\
\hline Phenolic compounds & +++ & +++ & - \\
\hline Anthocyanins & + & + & +++ \\
\hline Flavonoids & - & - & +++ \\
\hline \multicolumn{4}{|l|}{ Aqueous extract } \\
\hline Alkaloids & +++ & - & +++ \\
\hline Phenolic compounds & +++ & - & +++ \\
\hline Flavonoids & + & - & - \\
\hline Reducing compounds & +++ & +++ & - \\
\hline
\end{tabular}

Legend: + (positive); - (negative) 


\subsection{Phytochemical Screening of the Hydroalcoholic Extracts of T. tuberosum}

In the same way, to the extracts we did a phytochemical screening and the results are presented in [Table 4].

\subsection{Total Phenol Content and Total Flavonoid Content of the Hydro Alcoholic Extracts of T. tuberosum}

Another aspect evaluated to the extracts was the content of total phenols and total flavonoids and the results are presented in [Table 5].

Table 3. Organoleptic characteristics and physicochemical parameters of hydroalcoholic extracts of different varieties of T. tuberosum.

\begin{tabular}{|c|c|c|c|}
\hline \multirow{2}{*}{ Parameters } & \multicolumn{3}{|c|}{ Results } \\
\hline & Yellow mashua & Pink mashua & Black mashua \\
\hline Organoleptic & $\begin{array}{l}\text { Slightly viscous liquid (less than the pink } \\
\text { variety), translucent, yellow-orange color, } \\
\text { characteristic smell }\end{array}$ & $\begin{array}{l}\text { Viscous liquid Little translucent } \\
\text { Yellow color Characteristic smell }\end{array}$ & $\begin{array}{l}\text { Slightly viscous liquid (less than the } \\
\text { yellow variety) Little translucent Wine } \\
\text { red color Characteristic smell }\end{array}$ \\
\hline $\mathrm{pH}$ & $3.92 / 0.02^{\mathrm{b}}$ & $4.22 / 0.01^{\mathrm{a}}$ & $4.06 / 0.03^{c}$ \\
\hline Total solids (\%) & $1.18 / 0.05^{\mathrm{e}}$ & $2.02 / 0.01^{\mathrm{d}}$ & $2.23 / 0.06^{\mathrm{f}}$ \\
\hline Refractive index & $1.3296 / 0.0002^{\mathrm{h}}$ & $1.3308 / 0.0001^{\mathrm{g}}$ & $1.3318 / 0.0002^{\mathrm{i}}$ \\
\hline Relative density $(\mathrm{g} / \mathrm{mL})$ & $1.0171 / 0.0006^{\mathrm{k}}$ & $1.0197 / 0.0002^{j}$ & $1.0221 / 0.0003^{1}$ \\
\hline
\end{tabular}

Legend: X/S: mean value of the determinations/standard deviation, $\mathrm{n}=3$. Equal letters in a row show that there are no significant differences ( $\mathrm{p}>0.05$ ) and different letters than if there are significant differences $(\mathrm{p}<0.05)$ for $95 \%$ confidence, according to Duncan.

Table 4. Phytochemical screening of hydroalcoholic extracts of T. tuberosum.

\begin{tabular}{cccc}
\hline Metabolites & \multicolumn{3}{c}{ Extracts } \\
\cline { 2 - 4 } Alcaloids & Pink Variety & Variety amarilla & Variety negra \\
Tannins/Phenols & - & - & - \\
Saponins & + & + & ++ \\
Flavonoids & + & + & + \\
Reducing substances & + & + & ++ \\
Mucílage & Light yellow & Intense yellow & ++ \\
Bitter and astringent principles & ++ & + & + \\
\hline
\end{tabular}

Legend: + possitive test; ++ very possitive test; - negative test; /doubtful test.

Table 5. Content of total phenols and total flavonoids in hydroalcoholic extracts of $T$. tuberosum.

\begin{tabular}{|c|c|c|}
\hline Extracts & Total phenols mg/mL $\quad \bar{X} \pm D S$ & Total flavonoids $\mathrm{mg} / \mathrm{mL} \quad \bar{X} \pm D S$ \\
\hline Yellow variety & $0.48 / 0.01^{\mathrm{b}}$ & $0.19 / 0.005^{\mathrm{b}}$ \\
\hline Pink variety & $0.31 / 0.01^{\mathrm{a}}$ & $0.28 / 0.01^{\mathrm{a}}$ \\
\hline Black variety & $0.66 / 0.01^{c}$ & $0.10 / 0.003^{c}$ \\
\hline
\end{tabular}

Legend: $\bar{X} \pm D S:$ mean value of the determinations/standard deviation for $\mathrm{n}=3$. Equal letters show that there are no significant differences $(p>0.05)$ and different letters than if there are significant differences $(p$ $<0.05$ ) for $95 \%$ confidence, according to Duncan. 


\subsection{Analysis of the Extracts by Gaseous Chromatography Coupled System-Mass Spectrometry}

The chromatograms from the hydro alcoholic extracts of the different varieties are presented in [Figure 3].

The components to which structures were assigned by comparison of their mass spectra with those of the equipment library are indicated in [Table 6].
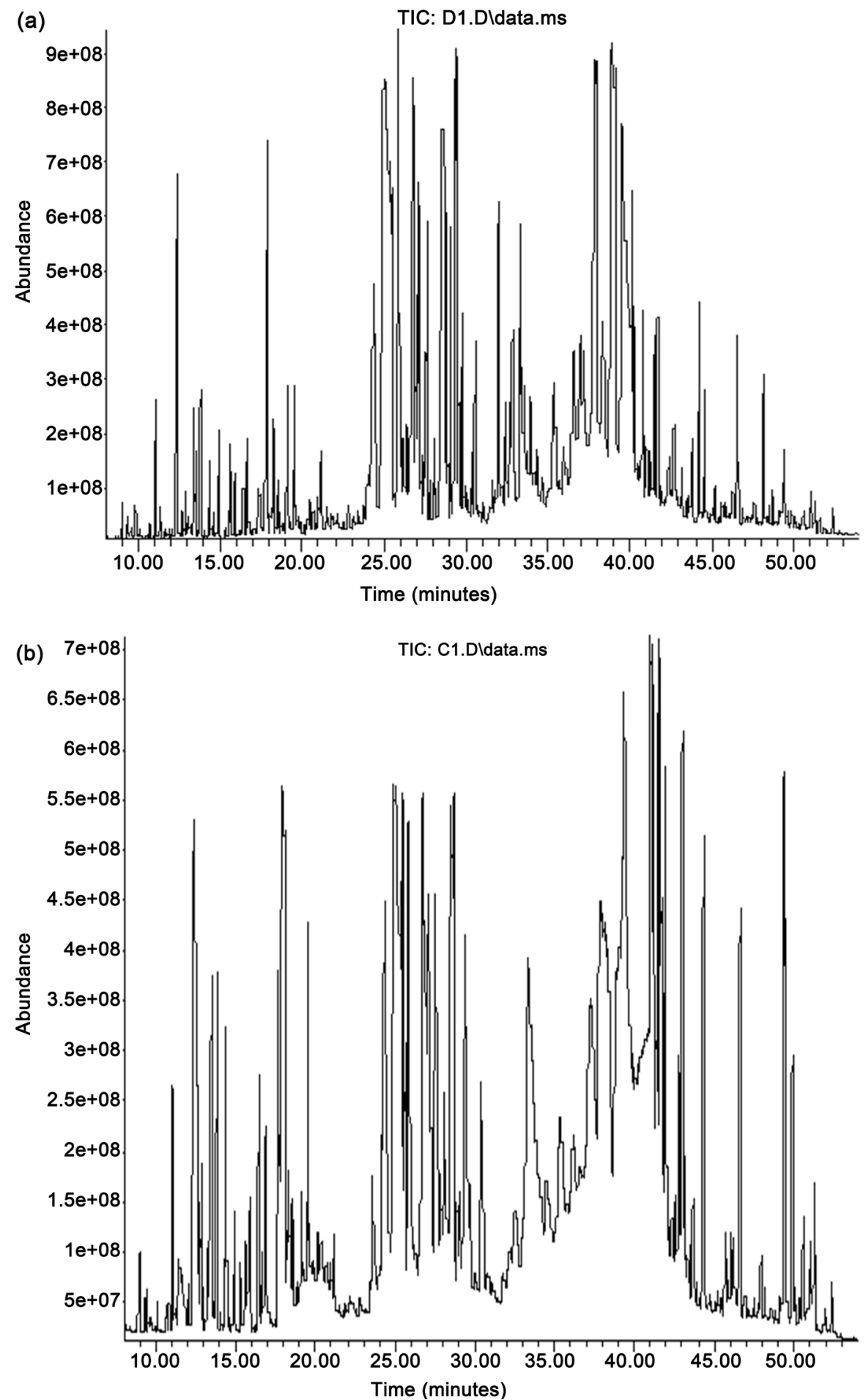


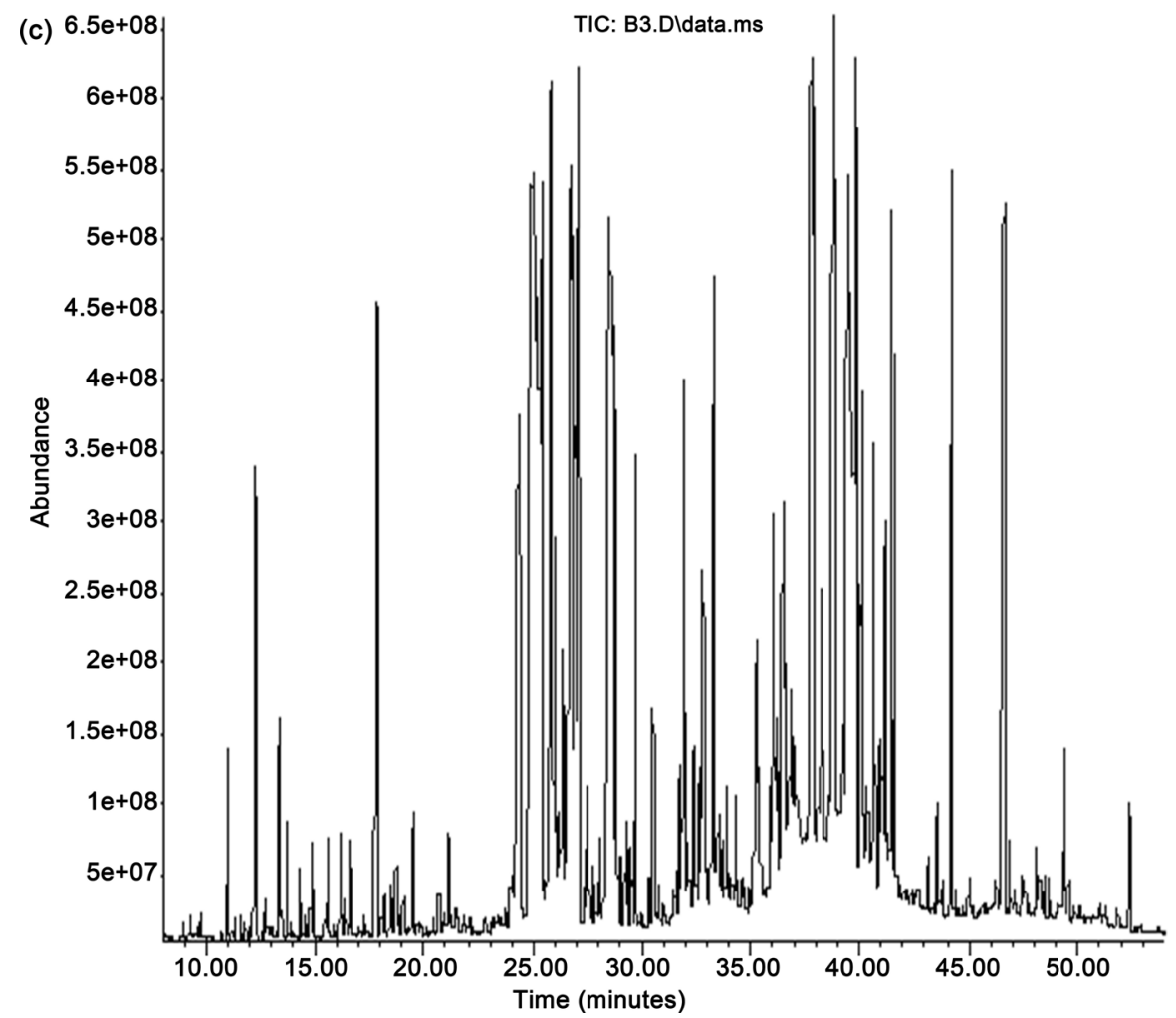

Figure 3. Chromatographic profile of ethanolic extracts of yellow (a), pink (b), and black (c) Tropaeolum tuberosum. Ruíz \& Pavón, Kuntze, (mashua).

\subsection{Antioxidant Activity of the Extracts}

The antioxidant activity of plant extracts depends greatly on its composition and the test system, so it is necessary to perform more than one type of test to measure it and thus have a measure of the mechanism of antioxidant action [27]. That is why in this work several methods were used for this analysis, among which are FRAP, DPPH and ABTS. The results achieved are presented in [Table 7].

\section{Discussion}

\subsection{Physicochemical Parameters and Phytochemical Screening of Raw Drugs}

Regarding the physicochemical parameters [Table 1], the black mashua had the highest residual moisture value and total ash, and the lowest value of insoluble ashes in hydrochloric acid, which is indicative that the minerals present are of the alkaline and alkaline earth type. The pink variety had the lowest percentage of moisture and total ashes. According to NRC [28] and Monteros [29], among the minerals, the most concentrated are phosphorus and magnesium, followed by zinc and iron with low contribution in $\mathrm{Na}$ and its high content in $\mathrm{K}$.

The phytochemistry of the T. tuberosum species has been studied for several decades. However, in compiled literature, comparative studies between tubers of different colors are missing. 
Table 6. Compounds identified by CG-EM in the hydroalcoholic extracts of the three varieties of Mashua.

\begin{tabular}{|c|c|c|c|}
\hline Peak & Retention time (min) & Compounds yellow variety & Abundance/S (\%) \\
\hline 1 & 11.805 & Serine & $0.69 / 0.00$ \\
\hline 2 & 13.747 & propanoic acid & $4.11 / 0.00$ \\
\hline 3 & 14.545 & Nonanoic acid & $1.37 / 0.10$ \\
\hline 4 & 15.14 & Treonine & $0.34 / 0.00$ \\
\hline 5 & 16.136 & 1-Aspartic acid & $6.85 / 0.01$ \\
\hline 6 & 21.12 & Arabinonic acid & $8.90 / 0.01$ \\
\hline 7 & 21.411 & D-(-)-Ribose & $2.06 / 0.00$ \\
\hline 8 & 23.369 & Arabinonic acid & $2.74 / 0.01$ \\
\hline 9 & 28.473 & glucitol & $5.14 / 0.01$ \\
\hline 10 & 27.788 & D-(+)-talofuranose & $4.45 / 0.00$ \\
\hline 11 & 30.323 & Myo-Inositol & $5.48 / 0.00$ \\
\hline 12 & 31.483 & Heptadecanoic acid & $4.80 / 0.04$ \\
\hline 13 & 32.625 & Linoleic acid & $13.36 / 0.01$ \\
\hline 14 & 32.751 & Linolenic acid & $11.30 / 0.00$ \\
\hline 15 & 33.511 & $A$-D-Galactofuranose-(-)-fructuose & $8.90 / 0.00$ \\
\hline 16 & 34.904 & Cholesta-7.9(11)-dien-3-ol & $4.795 / 0.00$ \\
\hline 17 & 43.135 & D-Glucopyranose & $8.56 / 0.00$ \\
\hline 18 & 51.271 & Palatinose & $4.80 / 0.00$ \\
\hline Peak & Retention time (min) & Compounds pink variety & Abundance/S (\%) \\
\hline 1 & 18.782 & Arachidonic acid & $6.49 / 0.02$ \\
\hline 2 & 21.504 & $\alpha$-linolenic acid & $6.25 / 0.05$ \\
\hline 3 & 21.883 & cis-5,8,11-eicosatrienoic acid & $4.06 / 0.03$ \\
\hline 4 & 21.755 & Estearic butil ester acid & $3.25 / 0.01$ \\
\hline 5 & 22.011 & $\mathrm{~N}$-mirystoil l-glicine & $2.84 / 0.01$ \\
\hline 6 & 29.699 & Palmític acid & $34.90 / 0.02$ \\
\hline 7 & 31.448 & $3 \beta$-5 $\alpha 11 \beta$-androstane3,11-diylbisoxy & $10.55 / 0.03$ \\
\hline 8 & 35.802 & $\beta$-dl-lyxopyranose & $31.66 / 0.00$ \\
\hline Peak & Retention time (min) & Compounds black variety & Abundance/S (\%) \\
\hline 1 & 11.788 & 3-buten-1-ol & $0.94 / 0.00$ \\
\hline 2 & 11.864 & Serine & $1.41 / 0.00$ \\
\hline 3 & 14.580 & Nonanoic acid & $3.76 / 0.00$ \\
\hline 4 & 14.821 & $2(3 \mathrm{H})$-Furanona & $3.14 / 0.00$ \\
\hline 5 & 15.722 & Nootkatone & $1.88 / 0.00$ \\
\hline 6 & 16.518 & Arachidonic acid & $0.65 / 0.46$ \\
\hline 7 & 19.243 & Alpha linoleic acid & $1.41 / 0.00$ \\
\hline 8 & 23.381 & Xylonic acid & $15.05 / 0.00$ \\
\hline 9 & 27.391 & Glucitol & $15.05 / 0.01$ \\
\hline 10 & 32.665 & 9,12-Octadecanoic acid & $44.21 / 0.01$ \\
\hline 11 & 48.552 & $\beta$-Sitosterol & $10.82 / 0.00$ \\
\hline
\end{tabular}

${ }^{*}$ Data are expressed as mean values/standard deviation $(n=3)$. 
In this work some differences were found between the three varieties studied, mainly in the intensity of the colorations [Table 2]; the pink mashua was the one that gave negative results for most of the metabolites tested. The presence of fatty compounds in the tubers has been reported by Simopoulos [30], which points out the presence of linoleic and $\alpha$-linoleic acids as the most abundant, in this work the fatty compounds were more abundant in the yellow and pink varieties. On the other hand, Albado et al. [31], has reported the presence of erucic acid in T. tuberosum in a percentage of $4.46 \%$ and $5.91 \%$ of dry tubers of two different samples using gas chromatography. The presence of triterpenoids was also detected, which were more abundant in the yellow variety and somewhat less in the black variety; these metabolites were reported by Chasquibol-Silva et al. [32], using the test of Lieberman-Burchard. Almagro [33] points out that the Lieberman-Buchard test does not allow to know the exact chemical structure of the molecules, nor the nature and conformation of the substituents. In addition, there are no other reports on the presence of phytosterols in T. tuberosum. Therefore, he considers that it would be interesting to study the chemical composition of phytosterols in the species to find out if they are responsible for some of the traditional uses such as anti-inflammatory, anti-diabetic and anti-cancer. The phenolic compounds were the metabolites that had greater intensity in the alcoholic extract for the yellow and pink varieties and in the aqueous extract for the yellow and black varieties. On the other hand, in the black mashua had greater intensity in the anthocyanidin test, these results are consistent with that reported by Chirinos [6] [11] [12], Campos [9], Tsao [34] y Tena \& Apaza [35]. The alkaloids gave positive results for the black and yellow varieties in the three types of extracts tested, which may be due to the presence of nitrogen compounds such as the alkamines reported by Zhao [36] and Apaza et al. [37].

\subsection{Organoleptic Parameters, Chemical Physicist and Phytochemical Screening of Extracts}

Once the extracts of the three varieties were obtained, their organoleptic and physicochemical characteristics were established [Table 3]. The main deference found in the organoleptic analysis was the coloring of the extracts. In relation to the physical parameters, all presented acidic characteristics with a lower $\mathrm{pH}$ for the yellow variety, which also presented the lowest amount of total solids. There were significant differences in all the parameters studied for the three varieties. For the phytochemical screening some differences were obtained compared with the drug extract, mainly in the presence of alkaloids, which may be due to the concentration of these product of solubility [Table 4].

Total phenol content and total flavonoids in hydroalcoholic extracts of $T$. tuberosum

The statistical analysis of the results allowed to verify significant differences in the content of total phenols and total flavonoids in the evaluated extracts [Table 5], the highest concentration of total phenols was presented by the extract from the black variety, while the pink variety differed by presenting greater total fla- 
vonoid content.

\subsection{Analysis of the Extracts by the Coupled Gas Chromatography-Mass Spectrometry System}

The analytical gas chromatograms of the different extracts were very complex, presenting numerous high intensity chromatographic peaks [Figure 3]. However, 18 compounds for the yellow variety, 8 for the pink variety and 12 for the black variety were identified by comparison of their mass spectra with those of the equipment library [Table 6]. The presence of acidic compounds, sugars and sterols stand out in all extracts. The yellow variety was the one with the highest number of acidic components (4), which reaffirms the lowest $\mathrm{pH}$ value found for the extract, also presented 7 compounds of a glycosidic nature, two amino acids and a steroid (derived from androstane), which confirm the results of phytochemical screening. The fatty acids found correspond to those reported in the literature [30]. In the pink variety, five fatty acids, one sugar, one carboxylic acid and one sterol (dehydro-cholesterol) were assigned, while in the black variety four acidic compounds, one amino acid, three sugars, two fatty acids and one sterol (dehydro-cholesterol).

In all the varieties studied, the presence of linoleic and linolenic fatty acids was found, but quantitative differences were found in their concentrations depending on the variety, Ramollo [38], also reported, the one with the highest content in fatty compounds being the yellow variety.

\subsection{Antioxidant Activity of the Extracts}

The results of the evaluation of the antioxidant activity by the three methods tested [Table 7], are analyzed below.

For the ferro-reducing activity of the three extracts evaluated, concentration dependent antioxidant activity was evidenced. At the lowest concentration tested, there were no significant differences between the extracts, however, from 80 $\mu \mathrm{g} / \mathrm{mL}$ the black mashua extract showed the highest equivalent $\mu \mathrm{M}$ values of ascorbic acid and $\mathrm{FeSO}_{4}$. The greatest capacity to reduce $\mathrm{Fe}^{3+}$ was manifested at the highest concentration evaluated.

The results allowed us to suggest that the three extracts have antioxidant activity, which translates into the equivalent $\mu \mathrm{M}$ values expressed as a function of the reference substances tested.

In the DPPH radical inhibition test against the concentration for each extract and reference substances tested, there is a tendency to increase the inhibition capacity of said radical as the concentration increases, the antioxidant activity being higher for the reference substances Vitamin $\mathrm{C}$ and Trolox, however, all three extracts were also able to inhibit this radical.

As can be seen in Table 7, there were significant differences in the percentages of DPPH radical inhibition between the extracts and in comparison with the reference substances at the same concentration. The highest values were evidenced 
Table 7. Antioxidant activity of extracts of Tropaeolum tuberosum Ruiz \& Pav. Kuntze.

\begin{tabular}{|c|c|c|c|c|c|c|}
\hline \multicolumn{7}{|c|}{ Ferro-reducing activity of the extracts of Tropaeolum tuberosum Ruiz \& Pav. Kuntze } \\
\hline \multirow{3}{*}{ Conc. $\mu \mathrm{g} / \mathrm{mL}$} & \multicolumn{6}{|c|}{ Ferro-reducing activity \pm SD } \\
\hline & \multicolumn{3}{|c|}{$\mu \mathrm{M}$ equivalents of ascorbic acid } & \multicolumn{3}{|c|}{$\mu \mathrm{M}$ equivalents of $\mathrm{FeSO}_{4}$} \\
\hline & Pink mashua & Yellow mashua & Black mashua & Pink mashua & Yellow mashua & Black mashua \\
\hline 40 & $66.38 \pm 3.85^{\mathrm{a}}$ & $74.16 \pm 6.66^{\mathrm{a}}$ & $74.72 \pm 9.18^{\mathrm{a}}$ & $58.90 \pm 3.29^{\mathrm{b}}$ & $65.57 \pm 5.71^{\mathrm{b}}$ & $66.04 \pm 7.86^{\mathrm{b}}$ \\
\hline 50 & $69.72 \pm 3.47^{c}$ & $88.61 \pm 6.73^{\mathrm{cd}}$ & $99.72 \pm 17.02^{\mathrm{d}}$ & $62.71 \pm 4.29^{\mathrm{e}}$ & $77.95 \pm 5.77^{\mathrm{ef}}$ & $87.47 \pm 14.59^{\mathrm{f}}$ \\
\hline 80 & $81.94 \pm 12.94^{\mathrm{g}}$ & $140.28 \pm 66.77^{g}$ & $263.61 \pm 34.21^{\mathrm{h}}$ & $72.23 \pm 11.09^{\mathrm{i}}$ & $92.23 \pm 12.14^{\mathrm{i}}$ & $227.95 \pm 29.32^{j}$ \\
\hline 100 & $91.94 \pm 12.72^{\mathrm{k}}$ & $190.83 \pm 29.05^{1}$ & $374.16 \pm 16.91^{\mathrm{m}}$ & $80.80 \pm 10.91^{\mathrm{n}}$ & $165.57 \pm 24.90^{\circ}$ & $326.04 \pm 16.49^{p}$ \\
\hline \multirow[t]{2}{*}{150} & $115.27 \pm 15.12^{\mathrm{q}}$ & $270.83 \pm 12.58^{\mathrm{r}}$ & $474.71 \pm 15.03^{\mathrm{s}}$ & $100.80 \pm 12.96^{\mathrm{t}}$ & $220.80 \pm 15.80^{\mathrm{u}}$ & $408.90 \pm 12.88^{\mathrm{v}}$ \\
\hline & \multicolumn{6}{|c|}{ Radical Kidnapping Percentage DPPH (\%) \pm SD } \\
\hline Conc. $\mu \mathrm{g} / \mathrm{mL}$ & Pink mashua & \multicolumn{2}{|c|}{ Yellow mashua } & Black mashua & Vitamin C & Trolox \\
\hline 50 & $19.82 \pm 2.01^{\mathrm{a}}$ & \multicolumn{2}{|c|}{$31.99 \pm 3.48^{\mathrm{b}}$} & $47.37 \pm 3.96^{c}$ & $85.31 \pm 0.76^{\mathrm{d}}$ & $83.75 \pm 0.86^{\mathrm{e}}$ \\
\hline 100 & $30.74 \pm 0.79^{\mathrm{f}}$ & \multicolumn{2}{|c|}{$48.80 \pm 2.63^{\mathrm{g}}$} & $53.12 \pm 1.04^{\mathrm{h}}$ & $87.76 \pm 1.09^{\mathrm{i}}$ & $86.42 \pm 0.88^{\mathrm{i}}$ \\
\hline 150 & $38.64 \pm 5.54^{j}$ & \multicolumn{2}{|c|}{$55.31 \pm 5.50^{\mathrm{k}}$} & $75.22 \pm 2.18^{1}$ & $88.62 \pm 1.07^{\mathrm{m}}$ & $87.65 \pm 0.78^{\mathrm{m}}$ \\
\hline 200 & $60.04 \pm 2.71^{\mathrm{n}}$ & \multicolumn{2}{|c|}{$66.03 \pm 6.00^{\circ}$} & $77.58 \pm 1.41^{\mathrm{p}}$ & $89.38 \pm 0.61^{\mathrm{q}}$ & $88.70 \pm 0.94^{\mathrm{q}}$ \\
\hline \multirow[t]{2}{*}{250} & $63.10 \pm 2.48^{\mathrm{r}}$ & $75.45 \pm 1.54^{\mathrm{s}}$ & \multicolumn{2}{|c|}{$83.81 \pm 0.86^{\mathrm{t}}$} & $90.40 \pm 0.93^{\mathrm{u}}$ & $90.01 \pm 0.54^{\mathrm{u}}$ \\
\hline & \multicolumn{6}{|c|}{ Radical Kidnapping Percentage ABTS $\bullet+(\%) \pm$ SD } \\
\hline Conc. $\mu \mathrm{g} / \mathrm{mL}$ & Pink mashua & Yellow mashua & \multicolumn{2}{|c|}{ Black mashua } & Vitamin C & Trolox \\
\hline 500 & $21.10 \pm 1.54^{\mathrm{a}}$ & $33.89 \pm 1.76^{\mathrm{b}}$ & 41.87 & $1.79^{c}$ & $8 \pm 1.42^{\mathrm{d}}$ & $84.49 \pm 0.65^{\mathrm{d}}$ \\
\hline 600 & $23.92 \pm 1.63^{\mathrm{e}}$ & $40.20 \pm 2$ & 56.15 & $1.80^{\mathrm{g}}$ & $5 \pm 1.24^{\mathrm{h}}$ & $89.10 \pm 0.78^{\mathrm{h}}$ \\
\hline 700 & $57.82 \pm 1.45^{\mathrm{i}}$ & $63.94 \pm 2$ & 70.32 & $2.20^{\mathrm{k}}$ & $2 \pm 1.23^{1}$ & $90.87 \pm 1.20^{1}$ \\
\hline 800 & $62.64 \pm 1.53^{\mathrm{m}}$ & $70.92 \pm 1$ & 84.60 & $1.67^{\circ}$ & $3 \pm 1.11^{\mathrm{p}}$ & $91.79 \pm 1.41^{\mathrm{p}}$ \\
\hline 900 & $70.17 \pm 1.40^{\mathrm{q}}$ & $76.48 \pm 1$ & 87.86 & $1.76^{\mathrm{s}}$ & $7 \pm 1.06^{\mathrm{t}}$ & $94.54 \pm 1.02^{\mathrm{t}}$ \\
\hline & & & nhibitory concen & tion media $\left(\mathrm{IC}_{50}\right.$ & & \\
\hline & $669.40 \pm 0.85$ & $667.05 \pm 0$ & 657.55 & $2.33^{\mathrm{ab}}$ & $0 \pm 11.03^{\mathrm{b}}$ & $652.25 \pm 13.79^{\mathrm{ab}}$ \\
\hline
\end{tabular}

The mean $(n=3) \pm$ standard deviation (SD) is indicated. Different letters in a row indicate significant differences and equal letters that there are no significant differences, at the same concentration $(\mathrm{p} \leq 0.05)$, according to the Tukey multiple comparison test.

for vitamin C and trolox, followed by black mashua extract. However, the extracts of the pink and yellow variety also showed good antioxidant activity with percentages greater than $60 \%$ from $200 \mu \mathrm{g} / \mathrm{mL}$.

An important aspect to consider is the determination of the $\mathrm{IC}_{50}$ (concentration value at which 50\% inhibition of the maximum DPPH sequestration effect is reached), in this regard, there were no significant differences between yellow and black mashua extracts with respect to the two reference substances, which indicates a similar antioxidant behavior, an aspect that denotes the high antioxidant power of these extracts.

The percentages of inhibition of the ABTS radical, of the extracts, showed a high sequestration capacity (greater than $55 \%$ ) from $700 \mu \mathrm{g} / \mathrm{mL}$, being higher for 
the black variety extract. The statistical analysis of the results allowed to detect significant differences between the extracts at the same concentration with respect to the reference substances, which reached the highest percentages.

The analysis of the $\mathrm{IC}_{50}$ (concentration value at which $50 \%$ inhibition of the maximum abduction effect of ABTS is reached) allowed to verify a similar behavior between the three extracts with the trolox pattern and that of the black variety also with vitamin $\mathrm{C}$, which translates into a good sequestration ability and therefore a high antioxidant activity by the mechanism of action evaluated.

Considering the results of the three in vitro test methods, it was found that as the concentration of the extracts increased, the reducing power (FRAP test) and the anti-radical activity (DPPH and ABTS tests) of the extracts increased, manifesting a high antioxidant activity, although lower than the reference substances used. Of the three extracts evaluated, the one from the variety of black mashua was the one that showed the greatest antioxidant capacity by the three methods tested.

For the antioxidant activity of mashua extracts, there is information in the literature, both for raw and purified extracts, with differences between them. The antioxidant activity recorded in purple tubers may be mainly due to anthocyanins [39] [40], which are the best natural source of pigments.

The antioxidant activity of the yellow tubers of T. tuberosum may be due to phenolic derivatives (flavonoids, anthocyanins) and hydroxycinnamic acids generated by the hydrolysis of glucosinolates [41].

Oxidative stress is considered an important contributor to the pathogenesis of several chronic diseases, and for this reason antioxidant behavior is one of the most commonly determined biological activities in plant extracts. A wide variety of antioxidant assays are used to determine the activity of plant extracts, two of which are based on the elimination of the DPPH radical (2,2-diphenyl-1-picrylhydrazyl) (DPPH assay) and the activity potential of iron reduction (FRAP trial) [42].

Many use the DPPH and FRAP assays in their plant activity detection programs, presumably, assuming that a combination of the data would provide a better description of the antioxidant activity than that obtained from a single test [42].

The three methods used (DPPH, FRAP and ABTS) for the evaluation of the antioxidant activity of hydroalcoholic extracts of Tropaeolum tuberosum were spectrophotometric methods.

The DPPH test is widely reported [43] [44] [45] for the determination of antioxidant activity, it is not a very tedious method in terms of chemical preparation and implementation of the test and, therefore, can be used for its operational simplicity. The radical used (DPPH) is one of the few stable and commercially available organic nitrogen radicals [45] [46].

In the present study, the antioxidant activity of each sample was measured several times to test the reproducibility of the assay. The only disadvantage of 
this test is that it is not very profitable and is not suitable for measuring the antioxidant capacity of plasma, because proteins precipitate in the alcoholic reaction medium [45] [47]. As a result, this inconvenience was not appreciated because the extracts were hydroalcoholic and soluble in the alcoholic medium used.

The FRAP test is more tedious and time consuming in terms of preparing the chemicals in the work solution. It is a simple and economical method and does not require the use of any exclusive chemical. The results obtained are reproducible for all concentrations. Therefore, FRAP is a suitable method for the determination of antioxidant activity.

The ABTS test uses ABTS radicals performed by oxidation thereof with potassium persulfate. Therefore, this analysis takes a long time in terms of waiting for ABTS radicals to be generated, since it takes about 12 - 16 hours for the reaction to take place, unlike the DPPH test where you do not have to wait for the radicals to be generated. However, once the radicals are generated, it is a very simple test in terms of their realization. The ABTS radical is soluble in water and organic solvents, which allows the determination of the antioxidant capacity of hydrophilic and lipophilic compounds/samples [45]. A major drawback of this test is that the radicals formed are not very stable and the results are sometimes not reproducible. However, this assay is also widely reported for the measurement of antioxidant activity.

The synergism between the antioxidants in a mixture causes that the antioxidant activity depends not only on its concentration but on the interaction between them. The antioxidant capacity of an extract is not only given by the sum of the antioxidant capacities of each of its components, it also depends on the microenvironment in which they are found. The compounds interact with each other and may produce synergistic or inhibitory effects [48].

\section{Conclusions}

Significant differences were found in the physical chemical parameters as well as in the intensity of the coloration of the qualitative tests between the three varieties of mashua studied.

The highest concentration of total phenols was presented by the extract from the black variety, while the pink variety differed by presenting greater total flavonoid content.

Differences were also detected in the chemical components identified by GC-EM for the three varieties.

It was found that as the concentration of the extracts increased, the reducing power (FRAP test) and the anti-radical activity (DPPH and ABTS tests) of the extracts increased, manifesting a high antioxidant activity, although lower than the reference substances used. Of the three extracts evaluated, the one from the variety of black mashua was the one that showed the greatest antioxidant capacity by the three methods tested. 


\section{Acknowledgements}

To ESPOL (University, Polytechnic School of the Coast), for the support in carrying out the study.

\section{Authors' Contribution}

MEJ, worked on the experimental design of the work and on its writing. YGG and MMM, performed the results processing and collaborated in the writing of the work. IChG, performed the chromatographic analysis and participated in the review of the work.

\section{Conflicts of Interest}

The authors declare no conflicts of interest regarding the publication of this paper.

\section{References}

[1] Rosset, P. (2003) Food Sovereignty: Global Rallying Cry of Farmer Movements. Food First Backgrounder, 9, No. 4.

[2] Barrera, V.C.T. and Monteros, A. (2004) Raíces y Tubérculos Andinos: Alternativas para la conservación y uso sostenible en el Ecuador. Serie: Conservación y uso de la biodiversidad de raíces y tubérculos andinos: Una década de investigación para el desarrollo (No 4). Instituto Nacional Autónomo de Investigaciones Agropecuarias, Centro Internacional de la Papa, Agencia Suiza para el Desarrollo y la Cooperación. Quito, Ecuador, Lima, Perú, 176 p.

[3] CIP (Centro Internacional de la Papa) (2015) Oca, ulluco y mashua. Lima, Perú. https://cipotato.org/es/raices-y-tuberculos/oca-ulluco-y-mashua/

[4] Aruquipa, R., Trigo, R., Bosque, H., Mercado, G. and Condori, J. (2016) El Isaño (Tropaeolum tuberosum) un cultivo de consumo y medicina tradicional en Huatacana para el beneficio de la población boliviana. Revista de Investigación e Innovación Agropecuaria y de Recursos Naturales, 3, 146-151.

[5] Cortez Báez, A.Y. Estudio del tiempo de conservación de una bebida nutraceútica a partir de mashua. Tropaeolumtuberosum. Tesis. Universidad Técnica del Norte. Ibarra, Ecuador.

http://repositorio.utn.edu.ec/bitstream/123456789/5968/1/03\%20EIA\%20418\%20T RABAJO\%20DE\%20GRADO.pdf

[6] Chirinos, R., Campos, D., Costa, N., Arbizu, C., Pedreschi, R. and Larondelle, Y. (2008) Phenolic Profiles of Andean Mashua (Tropaeolum tuberosum Ruíz \& Pavón) Tubers: Identification by HPLC-DAD and Evaluation of Their Antioxidant Activity. Food Chemistry, 106, 1285-1298. https://doi.org/10.1016/j.foodchem.2007.07.024

[7] Villacres, E., Quelal, M. and Álvarez, J. (2013) Nutrición, Procesamiento y Gastronomía de Raíces y Tubérculos Andinos en Ecuador: Una Revisión Bibliografía de Papa, Melloco, Oca, Mashua, Zanahoria Blanca y Jícama. http://repositorio.iniap.gob.ec/bitstream/41000/2816/1/iniapsc302.pdf

[8] Morillo, C.A.C., Morillo, C.Y. and Tovar, L.Y.P. (2016) Caracterización molecular de cubios (Tropaeolum tuberosum Ruíz y Pavón) en el departamento de Boyacá. Revista De Ciencias Agrícolas, 33, 32-42. https://doi.org/10.22267/rcia.163302.50

[9] Campos, D., Noratto, D., Chirinos, R., Arbizu, C., Roca, W. and Cisneros-Zevallos, 
L. (2006) Antioxidant Capacity and Secondary Metabolites in Tour Species of Andean Tuber Crops: Native Potato (Solanum sp.), Mashua (Tropaeolum tuberosum Ruíz y Pavón), Oca (Oxalis tuberosa Molina) y Olluco (Ollucus tuberosus Caldas). Journal of the Science of Food and Agriculture, 86, 1481-1488. https://doi.org/10.1002/jsfa.2529

[10] Chirinos, R., Campos, D., Betalleluz, I., Giusti, M.M., Schwartz, S.J., Quingguo, T., et al. (2006) Cromatografía líquida de alta resolución con detección de matrices de fotodiodos (HPLC-DAD)/HPLC-Espectrometría de Masas (MS) de antocianinas de tubérculos andinos Mashua (Tropaeolum tuberosum Ruiz \& Pavón) y su contribución a la actividad antioxidante Global. Journal of Agricultural and Food Chemistry, 54, 7089-7097. https://doi.org/10.1021/jf0614140

[11] Chirinos, R., Campos, D., Arbizu, C., Rees, J.-F., Roez, H. and Larondelle, Y. (2007) Effect of Genotype, Maturity Stage and Post-Harvest Storage on Phenolic Compounds, Carotenoid Content and Antioxidant Capacity of Andean Mashua Tubers (Tropaeolum tuberosum Ruíz y Pavón). Journal of the Science of Food and Agriculture, 87, 437-446. https://doi.org/10.1002/jsfa.2719

[12] Chirinos, R., Rogez, H., Campos, D., Pedreschi, R. and Larondelle, Y. (2007) Optimization of Extraction Conditions of Antioxidant Phenolic Compounds from Mashua (Tropaeolum tuberosum Ruíz \& Pavón) Tubers. Separation and Purification Technology, 55, 217-225. https://doi.org/10.1016/j.seppur.2006.12.005

[13] WHO (World Health Organization) (2011) Quality Control Methods for Medicinal Plant Materials. WHO/PHARM/92.559. Updated Edition of Quality Control Methods for Medicinal Plant Materials. Geneva.

[14] Miranda, M.M. and Cuéllar, A.C. (2000) Manual de prácticas de laboratorio. Farmacognosia y productos naturales. Universidad de la Habana. Ciudad Habana, $\mathrm{Cu}-$ ba, 1-7, 18-32.

[15] Pourmorad, F., Hosseinimerhr, S.J. and Shahabimajd, N. (2006) Antioxidant Activity, Phenol and Flavonoid Contents of Some Selected Iranian Medicinal Plants. African Journal of Biotechnology, 5, 1142-1145.

[16] Memnune, S., Hilal, Y., Neva, G., Bulent, C., Zeynep, E. and Sezai, E. (2009) Total Phenolic Content, Antioxidant and Antimicrobial Activities of Some Medicinal Plants. Pakistan Journal of Pharmaceutical Sciences, 22, 102-106.

[17] Kale, A., Gaikwad, S., Mundhe, K., Deshpande, N. and Salvekar, J. (2010) Quantification of Phenolics and Flavonoids by Spectrophotometer from Juglansregia. International Journal of Pharma and Bio Sciences, 1, 1-4.

[18] Chlopicka, J., Pasko, P., Gorinstein, S., Jedryas, A. and Zagrodzki, P. (2012) Total Phenolic and Total Flavonoid Content, Antioxidant Activity and Sensory Evaluation of Pseudocereal Breads. LWT-Food Science and Technology, 46, 548-555. https://doi.org/10.1016/j.lwt.2011.11.009

[19] Chang, C., Yang, M., Wen, H. and Chern, J. (2002) Estimation of Total Flavonoid Content in Propolis by Two Complementary Colorimetric Methods. Journal of Food and Drug Analysis, 10, 178-182.

[20] Saitta, M., Curto, S.L., Salvo, F., Di Bella, G. and Dugo, G. (2002) Gas Chromatographic Tandem Mass Spectrometric Identification of Phenolic Compounds in Sicilian Olive Oils. Analytica Chimica Acta, 466, 335-344.

https://doi.org/10.1016/S0003-2670(02)00572-X

[21] Benzie, I.F.F. and Strain, J.J. (1996) The Ferric Reducing Ability of Plasma (FRAP) as a Measure of "Antioxidant Power": The FRAP Assay. Analytical Biochemistry, 239, 70-76. https://doi.org/10.1006/abio.1996.0292 
[22] Brand-Williams, W., Cuvelier, M.E. and Berset, C. (1995) Use of Free Radical Method to Evaluate Antioxidant Activity. LWT-Food Science and Technology, 28, 25-30. https://doi.org/10.1016/S0023-6438(95)80008-5

[23] Kedare, S.B. and Singh, R.P. (2011) Genesis and Development of DPPH Method of Antioxidant Assay. Journal of Food Science and Technology, 48, 412-422. https://doi.org/10.1007/s13197-011-0251-1

[24] Re, R., Pellegrini, N., Proteggente, A., Pannala, A., Yang, M. and Rice-Evans, C. (1999) Antioxidant Activity Applying an Improved ABTS Radical Cation Decolorization Assay. Free Radical Biology and Medicine, 26, 1231-1237. https://doi.org/10.1016/S0891-5849(98)00315-3

[25] Agudo, L.M. (2010) Técnicas para la determinación de compuestos antioxidante en alimentos. Autodidacta. Revista de la Educación en Extremadura, 27-34.

[26] Arnao, M.B., Cano, A. and Acosta, M. (2001) The Hydrophilic and Lipophilic Contribution to Total Antioxidant Activity. Food Chemistry, 73, 239-244. https://doi.org/10.1016/S0308-8146(00)00324-1

[27] Song, F.L., Gan, R.Y., Zhang, Y., Xiao, Q., Kuang, L. and Li, H.B. (2010) Total Phenolic Contents and Antioxidant Capacities of Selected Chinese Medicinal Plants. International Journal of Molecular Sciences, 11, 2362-2372. https://doi.org/10.3390/ijms11062362

[28] National Research Council (NRC) (1989) Lost Crops of the Incas: Little-Known Plants of the Andes with Promise for Worldwide Cultivation. National Academy Press, Washington, 67-73.

[29] Monteros Altamirano, A.R. (1996) Estudio de la Variación Morfológica e Isoenzimatica de 78 entradas de Mashua (Tropaeolum tuberosum R \& P.). "Santa Catalina"-INIAP (Ing Thesis). Facultad de Ciencias Agricolas. Universidad Central de Ecuador, EC.

[30] Simopoulos, A.P. (2002) The Importance of the Ratio of Omega-6/Omega-3 Essential Fatty Acids. Biomedicine \& Pharmacotherapy, 56, 365-379. https://doi.org/10.1016/S0753-3322(02)00253-6

[31] Albado, P.E., Alvarado, I.D., Rodríguez, A.M., Robles, R.M. and Sáez, F.G. (2012) Actividad biológica de los tubérculos de Tropaeolum tuberosum (Mashua) sobre Globodera pallida y Meloidogyne spp. The Biologist, 10, 32.

[32] Chasquibol-Silva, N., Delmás-Robles, D.I., Rivera-Castilla, D., Lengua-Calle, R.L., Aguirre-Medrano, R., Bazán-Gutierrez, D., Becerra-Vásquez, E. and Bautista-Castro, M. (1999) Contribución a la normalización de productos tradicionales andinos: Maca, Kiwicha, Cañihua, Mashua. Revista Peruana de Química e Ingeniería Química, 2, 9-21.

[33] Almagro, L., Miras-Moreno, B. and Sabater-Jara, A.B. (2016) Bioactivity of Phytosterols and Their Production in Plant in Vitro Cultures. Journal of Agricultural and Food Chemistry, 38, 7049-7058. https://doi.org/10.1021/acs.jafc.6b02345

[34] Tsao, R. (2010) Chemistry and Biochemistry of Dietary Polyphenols. Nutrients, 12, 1231-1246. https://doi.org/10.3390/nu2121231

[35] Tena Pé, V. and Luis Nestor, A.T. (2019) Ethnobotanical Uses, Secondary Metabolites and Biological Activities of Mashua (Tropaeolum tuberosum Ruíz \& Pavón). Journal of Ethnopharmacology, 247, Article ID: 112152. https://doi.org/10.1016/j.jep.2019.112152

[36] Zhao, J., Muhammad, I., Dunbar, D.C., Mustafa, J. and Khan, I.A. (2005) New alkamides from maca (Lepidium meyenii). Journal of Agricultural and Food Chemi- 
stry, 3, 690-693. https://doi.org/10.1021/jf048529t

[37] Apaza, T.L., Tena, P.V., Serban, A.M., Alonso, N.M.J. and Rumbero, A. (2019) Alkamides from Tropaeolum tuberosum Inhibit Inflammatory Response Induced by TNF- $\alpha$ and NF- $\kappa$ B. Journal of Ethnopharmacology, 235, 199-205. https://doi.org/10.1016/j.jep.2019.02.015

[38] Ramallo, Z.R. (2004) Análisis exploratorio de los ácidos grasos del isaño (Tropaeolum tuberosum). Revista Investigación \& Desarrollo, 4, 71-77. https://doi.org/10.23881/idupbo.004.1-9i

[39] Martín, J., Kuskoski, E.M., Navas, M.J. and Asuero, A.G. (2017) Antioxidant Capacity of Anthocyanin Pigments. In: Justino, G., Eds., Flavonoids-From Biosynthesis to Human Health, National and University Library in Zagreb, Croatia, 205-256.

[40] Khoo, H.E., Azlan, A., Tang, S.T. and Lim, S.M. (2017) Anthocyanidins and Anthocyanins: Colored Pigments as Food, Pharmaceutical Ingredients, and the Potential Health Benefits. Food \& Nutrition Research, 61, Article ID: 1361779. https://doi.org/10.1080/16546628.2017.1361779

[41] Vicas, S.I., Teusdea, A.C., Carbunar, M., Socaci, S.A. and Socaciu, C. (2013) 1512 Glucosinolates Profile and Antioxidant Capacity of Romanian Brassica Vegetables Obtained by Organic and Conventional Agricultural Practices. Plant Foods for Human Nutrition, 68, 313-321. https://doi.org/10.1007/s11130-013-0367-8

[42] Clarke, G., Ting, K.N., Wiart, C. and Fry, J. (2013) High Correlation of 2,2-Diphenyl-1-Picrylhydrazyl (DPPH) Radical Scavenging, Ferric Reducing Activity Potential and Total Phenolics Content Indicates Redundancy in Use of All Three Assays to Screen for Antioxidant Activity of Extracts of Plants from the Malaysian Rainforest. Antioxidants, 2, 1-10. https://doi.org/10.3390/antiox2010001

[43] Sreeramulu, D. and Raghunath, M. (2010) Antioxidant Activity and Phenolic Content of Roots, Tubers and Vegetables Commonly Consumed in India. Food Research International, 43, 1017-1020. https://doi.org/10.1016/j.foodres.2010.01.009

[44] Heleno, S.A., Barros, L., Martins, A., Queiroz, M.J.R.P., Santos-Buelga, C. and Ferreira, I.C.F.R. (2012) Fruiting Body, Spores and in Vitro Produced Mycelium of Ganoderma lucidum from Northeast Portugal: A Comparative Study of the Antioxidant Potential of Phenolic and Polysaccharidic Extracts. Food Research International, 46, 135-140. https://doi.org/10.1016/j.foodres.2011.12.009

[45] Pooja, S. and Modi, H.A. (2015) Comparative Study of DPPH, ABTS and FRAPAssays for Determination of Antioxidant Activity. International Journal for Research in Applied Science \& Engineering Technology, 3, 636-641.

[46] Huang, D., Ou, B. and Prior, R.L. (2005) The Chemistry behind Antioxidant Capacity Assays. Journal of Agricultural and Food Chemistry, 5, 1841-1856. https://doi.org/10.1021/jf030723c

[47] Magalhaes, L.M., Segundo, M.A., Reis, S. and Lima, J.L.F.C. (2008) Methodological Aspects about in Vitro Evaluation of Antioxidant Properties. Analytica Chimica Acta, 613, 1-19. https://doi.org/10.1016/j.aca.2008.02.047

[48] Kuskoski, E.M., Agustín, G.A., Troncosa, M.A., Manzini-Filho, J. and Roseane, F. (2005) Aplicación de diversos métodos químicos para determinar la actividad antioxidante en pulpa de frutos. Food Science and Technology, 25, 726-732. https://doi.org/10.1590/S0101-20612005000400016 